\title{
Oichnus taddeii, a new fossil trace produced by capulids on brachiopod shells
}

\section{Emma RUGGIERO* \& Pasquale RAIA}

Dipartimento di Scienze della Terra, Ambiente e Risorse, Università di Napoli Federico II, Lago San Marcellino 10, 80138, Napoli, Italy; emma.ruggiero@unina.it; pasquale.raia@unina.it

* Corresponding author

Ruggiero, E. \& Raia, P. 2014. Oichnus taddeii, a new fossil trace produced by capulids on brachiopod shells [Oichnus taddeii, una nueva traza fósil producida por capúlidos sobre conchas de braquiópodos]. Spanish Journal of Palaeontology, 29 (1), 15-24.

\begin{abstract}
We describe the new ichnospecies Oichnus taddeii, a bioerosion trace left by parasitic capulids on fossil brachiopods, prevalently Quaternary Terebratula species. We present the diagnosis of the new ichnospecies and discuss its status. The trace was previously attributed to either Oichnus or Lacrimichnus ichngenera. We provide a statistical assessment of the trace distribution on brachiopod shells, in order to infer the capulid behavior, and the parasitic activity the trace represents.
\end{abstract}

Keywords: Bioerosion, parasitism, capulids, brachiopods, Quaternary.

\section{RESUMEN}

Se describe la nueva icnoespecie Oichnus taddeii, una traza de bioerosión producida por capúlidos parásitos observada sobre braquiópodos fósiles, principalmente en especies cuaternarias del género Terebratula. Se presenta la diagnosis de la nueva icnoespecie y se discute su estatus. La traza había sido previamente atribuida a los icnogéneros Oichnus o Lacrimichnus. Se proporciona una evaluación estadística de la distribución de la traza en las conchas de los braquiópodos en vistas a inferir el comportamiento del capúlido y la actividad parasitaria que la traza representa.

Palabras clave: Bioerosión, parasitismo, capúlidos, braquiópodos, Cuaternario. 


\section{INTRODUCTION}

Over more than 20 years, we have studied Pleistocene brachiopod assemblages, as large as to include thousands of individuals. These assemblages are rich in fossil traces, most of them being recognized to the ichnospecies level (Taddei Ruggiero, 1989, 1991, 1999; Taddei Ruggiero \& Annunziata, 2002). Among them, though, one trace was not consistently given a taxonomic attribution. This rare but clearly distinctive trace is a subcircular hole surrounded by a subelliptical area tangent to the hole. Similar traces are known in literature and usually attributed to capulid mesogastropod molluscs (e.g., Orr, 1962; Matsukuma, 1978).

Bioerosions left by capulids are known in the fossil record as well as in living organisms. Living capulids attach to either the rock bottom, or to living or dead shells. Capulids feed via an elongate proboscis which conveys food particles to the mouth. Capulids may act as independent suspension feeders, or behave as commensal or parasites (Bromley, 1981; Baumiller \& Gahn, 2002). On pectinids, capulids are usually found in either one of two different positions. At times they are found attached to the anterior half of the palleal border, in order to exploit the inhalant current flowing within the host, by inserting the proboscis in between the valves. Subcircular scars and a semilunar gap are produced on the host valves in the process. Rarely, a hole is produced through the shell and the mantle of the host, just in front and dorsally to the pectinid mouth.

Sharman (1956) studied the positioning of Capulus ungaricus on the living bivalves Chlamys opercularis, Pecten maximus, and Modiolus modiolus. This author demonstrated that Capulus preferentially attaches at the edge of the valves, away from the exhalant current. Faint subcircular scars are produced on the valves in the process.

Orr (1962) described the feeding habit of Capulus danieli. This species, living in New Caledonia, pierces both the shell and the mantle of the pectinid Comptopallium vexillum close to the umbo and leaves a scar around the hole. Since the internal organs of the bivalve are not heavily affected in the process. He referred to this activity as antagonistic symbiosis.

Matsukuma (1978) was the first to describe fossil traces bearing holes with Capulus-like imprints on shells of the bivalves Chlamys opercularis and Cryptopecten vesiculosus, from the Early Pleistocene of Japan. The bioerosion traces were exclusive to the umbo region of the left valve. The trace was compared to bioerosions due to living $C$. dilatatus on pectinids and thereby ascribed to this same species.

Taddei Ruggiero $(1989,1991)$ and Taddei Ruggiero \& Annunziata (2002) described bioerosion traces on shells of the Pleistocene brachiopod Terebratula scillae from Southern Italy. Among them, they referred to subcircular holes, located on the cardinal commissure. These traces present a slightly abraded area around the hole and tangent to it, which were attributed to capulids.

Kowalewski (1993, p. 72, table 1) reviewed predatory drillholes and assigned to the ichnogenus Oichnus the traces left by commensal capulids on bivalves and gastropods.

Bongrain (1995) studied bioerosion traces produced by capulids on Miocene pectinids collected in Aquitania (France). The traces appear as imprints on the shell margin of Gigantopecten gallicus. They were ascribed to Capulus sinuosus and, possibly, to C. neglectus as well. She explicitly considers the feeding activity of capulids as a graded tendency from commensalism to parasitism.

Taddei Ruggiero (1999, fig. G) showed a specimen of Terebratula terebratula (identified in the text as T. calabra) from the Gelasian calcarenites of Apulia (Southern Italy) bearing a subcircular hole surrounded by an abraded area. In addition, she figured a second individual bearing a hole in the commissure and an internal mould of a capulid individual on the dorsal valve. The trace was ascribed to the ichnogenus Oichnus.

Borghi (2001) figured a Capulus individual still attached on a T. terebratula shell (identified in the text as T. ampulla), collected in the Pleistocene silts of Stirone river (Northern Italy).

Santos et al. (2003) erected the ichnogenus Lacrimichnus. It includes traces left by gastropods (Crepidula) and bivalves (Ostreacea). These traces bear no hole. They are known in the fossil record from the Upper Miocene to the Holocene. Later, Santos et al. (2004) included capulids within the organisms presumed to leave Lacrimichnus traces.

Taddei Ruggiero \& Bitner (2008) and Taddei Ruggiero et al. (2009) synthesised current knowledge on bioerosion traces occurring on brachiopod shells, and their palaeoecological significance. They tentatively ascribed to Lacrimichnus those traces left on Terebrautula bearing both a hole and a surrounding attachment scar. They also pointed out that similar traces were found on the rhynconellid Aphelesia bipartita, from the Gelasian of Apulia (Southern Italy).

Herein we present further evidence to confirm the trace attribution to the activity of capulid gastropods. We establish with certainty its taxonomic position within the Oichnus ichnogenus, and propose a new ichnospecies for those traces bearing a hole surrounded by an attachment scar.

\section{MATERIAL AND METHODS}

The studied material belongs to several South Italian Pleistocene localities (Fig. 1a) and comprises:

Forty-two traces on Terebratula scillae from Calabrian sands collected at Gallina (Reggio Calabria, Figs 1b, 2 section G). 
Two traces on T. scillae from Calabrian sands at Albanese quarry (Lecce, Apulia, Figs 1c, 2 section A).

Seven traces on $T$. terebratula and 1 trace on Aphelesia bipartita from Gelasian calcarenites at Masseria Poggiofranco (Canne della Battaglia, Apulia, Figs 1d, 2 section P).

We collected and cleaned in the laboratory specimens from the sandy sediment they were included. Given the loose nature of sediments it was possible to polish specimens without losing shape information at all. We measured the major diameters of bioerosion trace on each specimen. Then, in order to understand if the trace placement on the valves is non-random, we analyzed their statistical distribution on the valves, partitioning the traces both per valve and per valve side. Frequency distribution in each category was analyzed by means of chi-squared distribution. This latter analysis was performed on the
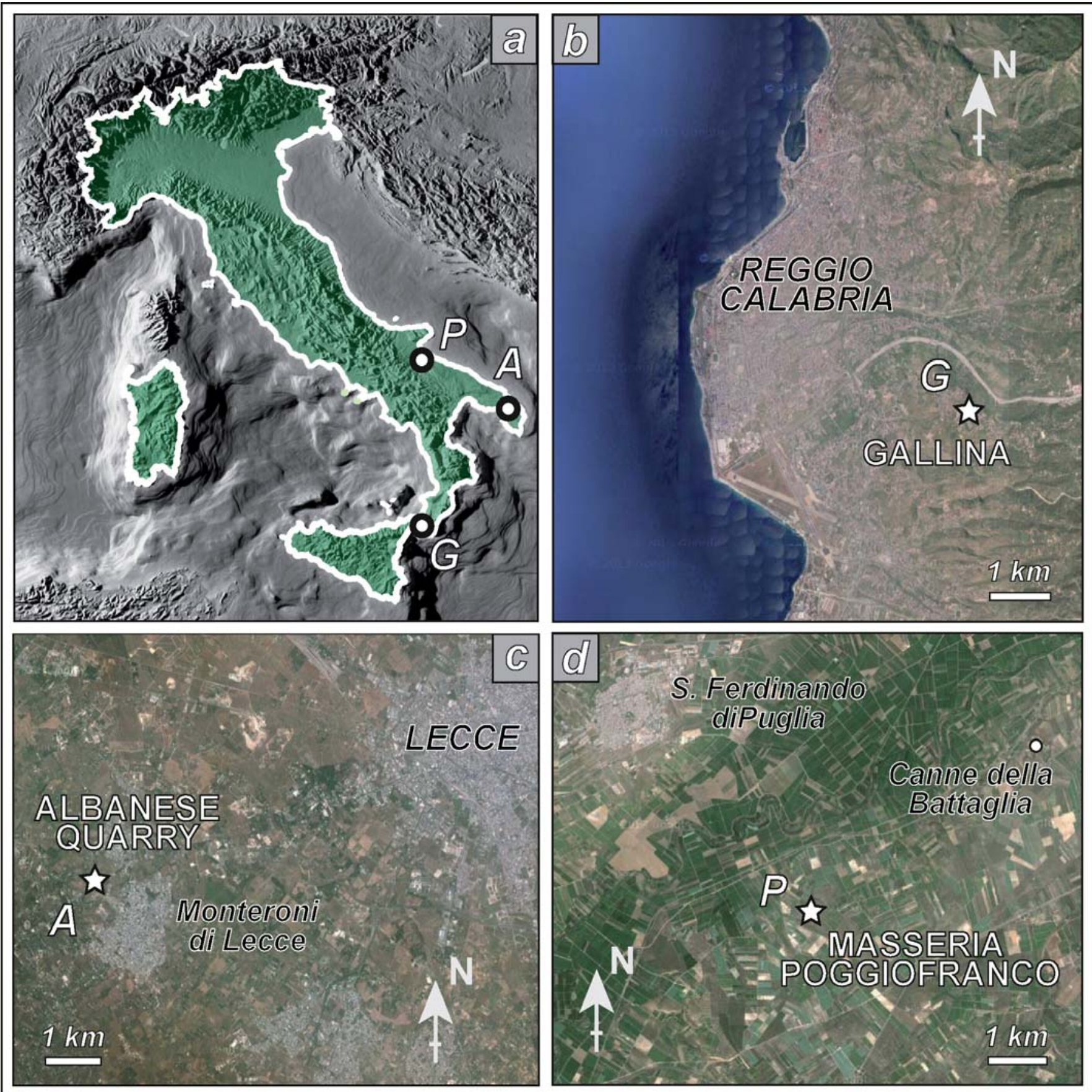

Figure 1. Location of the study sites. a) Map of the fossil sites over the Italian territory $G$ - Gallina, $A$ - Albanese quarry, $P$ - Masseria Poggiofranco. b) Gallina, near Reggio Calabria (Calabria). c) Albanese quarry, near Lecce (Apulia). d) Masseria Poggiofranco, near Canne della Battaglia (Apulia). 


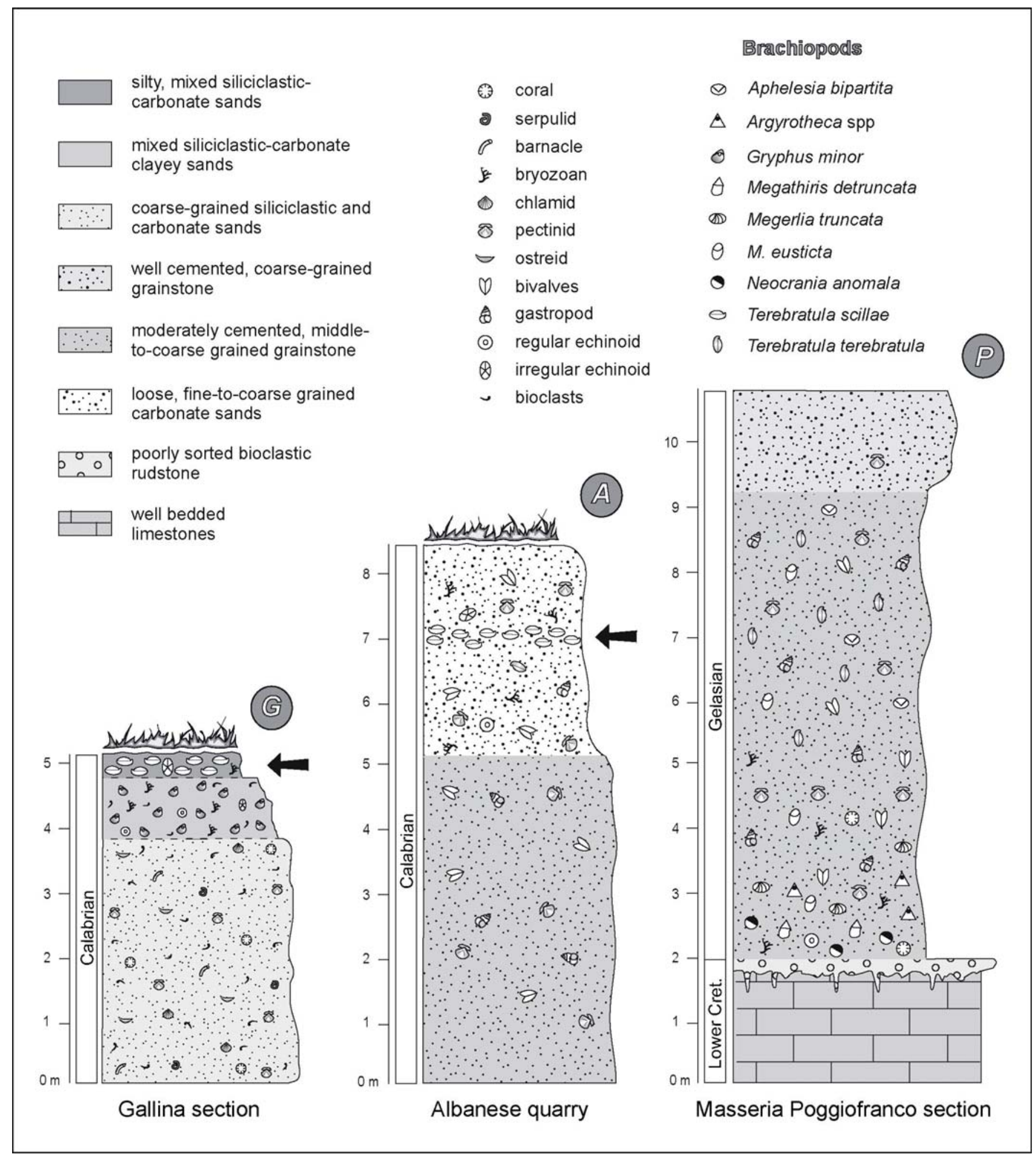

Figure 2. Stratigraphic successions of the studied sites; $G$ - Gallina section, $A$ - Albanese quarry, $P$ - Masseria Poggiofranco. Levels yielding Terebratula scillae are indicated with the arrow mark.

Terebratula scillae population coming from Calabrian calcarenites outcropping near Gallina. This is the single population showing the highest frequency of the bioerosion trace we refer here.
The stratigraphic framework used here follows Gibbard et al. (2010), who placed the Quaternary lower boundary at $2.588 \mathrm{Ma}$. This implies that the Gelasian age is here included in the Pleistocene instead on the Pliocene, as it formerly was. 


\section{DISTRIBUTION AND FREQUENCY OF OICHNUS TADDEII IN A MODEL BRACHIOPOD POPULATION}

We analysed 42 traces, 12 of them found on specimens with both valves in connexion. The distribution of holes and associated traces is not biased for valve (dorsal valve, $\mathrm{n}=16$, ventral valve, $\mathrm{n}=13$; chi-square test, $\mathrm{p}=0.58$ ), not for side either (right side, $\mathrm{n}=15$, left side, $\mathrm{n}=25$; chi-square test, $\mathrm{p}=0.11$ ). The traces always occur on one side only of the umbo, almost constantly at a distance of some $1 / 4$ of the shell length (mean $=0.24, \mathrm{sd}=0.06, \mathrm{n}=32$ ). The distribution of these distances is symmetrical.

The area of the shell affected by Capulus attachment is elliptical, with the minor axis being some $80 \%$ of the major axis (mean $=0.80, \mathrm{sd}=0.10, \mathrm{n}=31)$. The frequency of traces completed with a hole is $43.2 \%(19 / 44)$.

\section{SYSTEMATIC ICHNOLOGY}

Ichnogenus Oichnus Bromley, 1981

Oichnus taddeii isp. nov. (Figs 3, 4)

\section{Synonymies.}

1978 (fossil boreholes); Matsukuma, p. 33, text Figs. 3, 6, Tabb. 1, 2.

1989 (unnamed boring trace); Taddei Ruggiero, p. 620622, P1. 3, Figs.1-7.

1991 (unnamed boring trace); Taddei Ruggiero, p. 205206, Fig. 10.

1999 Oichnus isp.; Taddei Ruggiero, p. 169, Fig. 1G, H. 2002 Oichnus isp.; Taddei Ruggiero \& Annunziata, p. 45, 48, Pl. 1, Fig. 4.

2008 Lacrimichnus isp.; Taddei Ruggiero \& Bitner, p. 370, Fig. 4e.

2009 Lacrimichnus isp.; Taddei Ruggiero et al., p. 10-11, Fig. 9 b,c,d.

Derivatio Nominis. The ichnospecies is dedicated to the late Roberto Taddei, former Professor of Botany at the University of Naples Federico II, life-long amateur palaeontologist, and careful companion of a life to one of us (ER) who recently passed away.

Type material. Holotype: Trace $\mathrm{n}^{\circ} 2063$ on Terebratula scillae (Fig. 3a). Paratypes: Traces $n^{\circ} 343$ (Fig. 3b), 323 (Fig. 3c), 345 (Fig. 3d).

Type horizon and locality. Calabrian (Early Pleistocene), Gallina, Calabria, Southern Italy.
Diagnosis. Subcircular holes of 0.74 to $3.7 \mathrm{~mm}$ in diameter. The hole is perpendicular to the shell outer surface, tangentially surrounded by a slightly abraded, subelliptical area, with diameters ranging from 4.2 to $33 \mathrm{~mm}$.

Description. Subcircular hole on brachiopod valves (mainly on Terebratula) of 0.74 to $3.7 \mathrm{~mm}$ in diameter, surrounded by an elliptical area which is 4.2 to $33 \mathrm{~mm}$ in diameter. Holes run tangent to this area and perpendicular to the shell surface. They occur in the posterior part of the shell, close to the cardinal area. The holes usually occur before the cardinal teeth, on either sides of the umbo. Three of the studied specimens bear holes on both sides of the umbo (Fig. 3e). Holes mostly occur in the shell commissure, implying both valves. Out of our observations, only 5 specimens bear a hole affecting a single valve (Fig. 3f). We noted that in 3 different specimens there are 2 holes, very close to each other (Figs $3 \mathrm{~g}-\mathrm{h})$. The affected brachiopod usually reacts to the hole produced by the capulid by overgrowth of the secondary shell layer around the hole (Fig. 3d). This may end up with the shell of the host resisting perforation. A smooth margin was in fact observed just 3 times.

The present ichnospecies is limited to the Quaternary.

Remarks. The present trace is usually attributed to capulid gastropods (Orr, 1962; Matsukuma, 1978) and thereby assigned to the ichnogenus Oichnus by Kowalewski (1993). Although in the past we have assigned the trace to either Lachrimichnus (Taddei Ruggiero \& Bitner, 2008; Taddei Ruggiero et al., 2009) or to Oichnus (Taddei Ruggiero, 1999; Taddei Ruggiero \& Annunziata, 2002), we never faced in depth the issue of its real taxonomic position.

Herein, we present strong evidence that the trace actually has to be attributed to Oichnus ichnogenus. According to Santos et al. (2003) diagnosis, Lacrimichnus refers to surface marks with oval to slightly ellipsoidal margins. Santos et al. (2004) refer to Capulus as a potential producer of Lacrimichnus for the first time, albeit the trace and the producing Capulus were never found together. Here, we found this association in our brachiopod samples, and even fossilized Capulus still on Terebratula shell. Santos et al. (2003) diagnosis points out that Lacrimichnus is devoid of any hole, which we conversely find in our specimens. As such, we propose to classify the capulidmade trace into the ichnogenus Oichnus and to erect a new ichnospecies from the studied material.

Oichnus was erected by Bromley (1981) and emended by Nielsen \& Nielsen (2001). The latter authors noted that "The hole may pass right through the substrate as a penetration, where the substrate is a thin shell; or end within the substrate as a shallow to deep depression or short, subcylindrical pit". We therefore erect a new Oichnus species, O. taddeii. We decided to name a new 


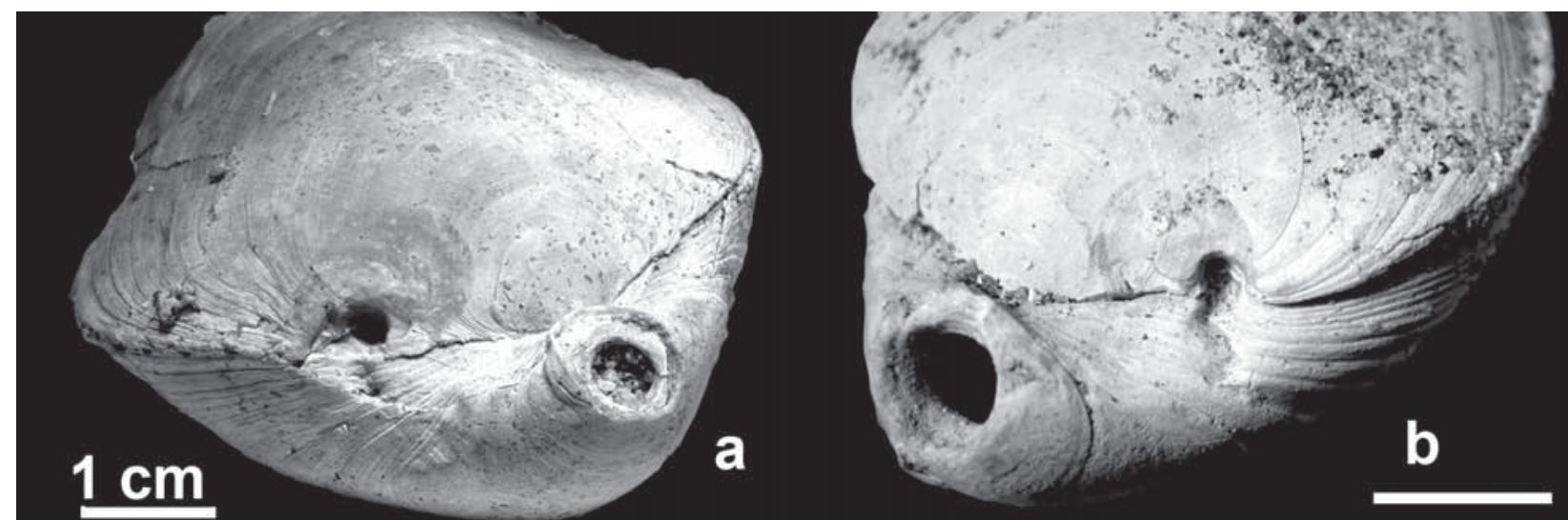

C
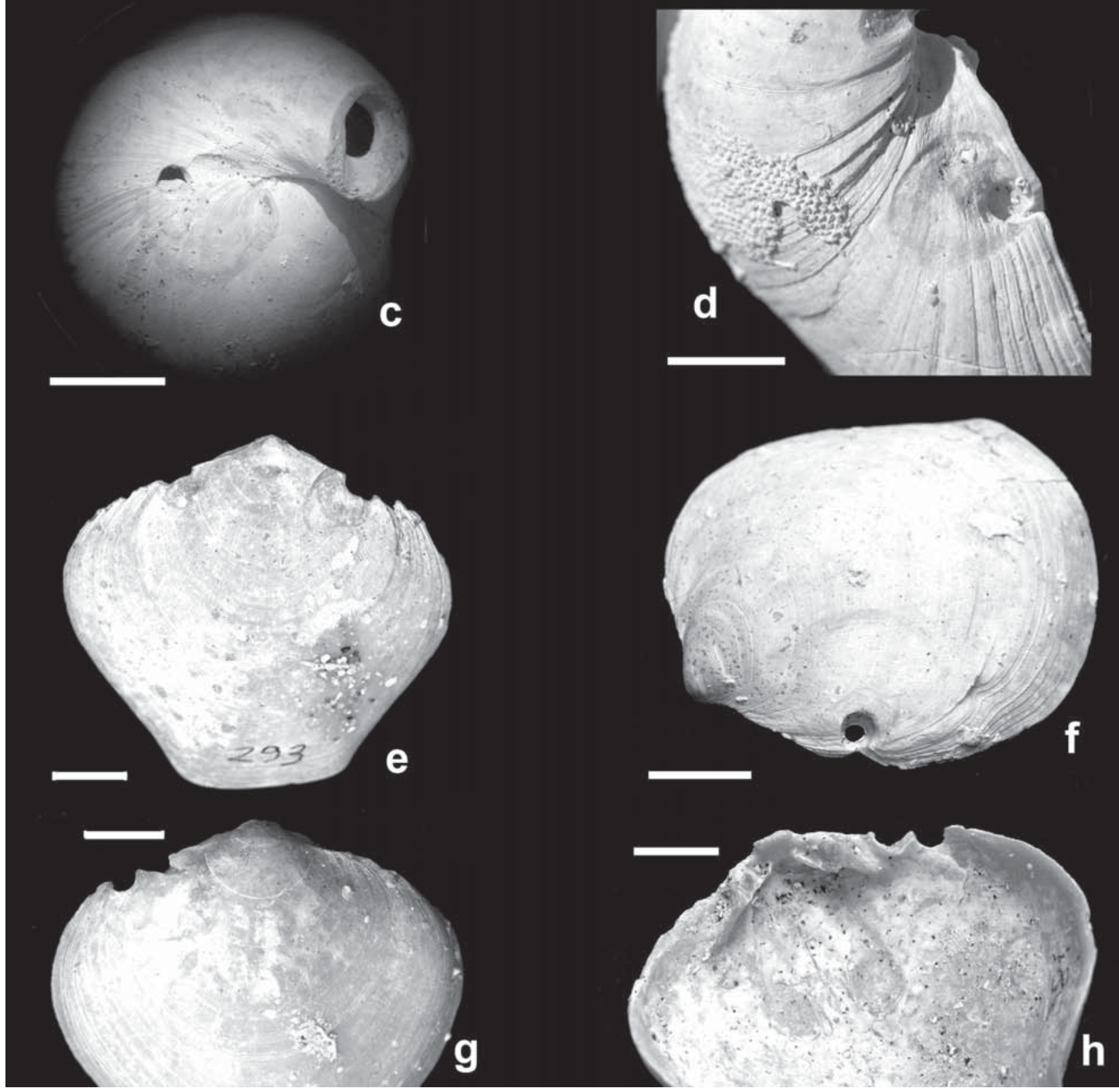

Figure 3. Oichnus taddeii isp. nov. All specimens are on Terebratula scillae shell from the Calabrian sands near Gallina (Reggio Calabria, Southern Italy). a) Holotype: trace $n^{\circ}$ 2063. b) Paratype $1, n^{\circ} 343$. c) Paratype 2, $n^{\circ} 323$. d) Paratype $4, n^{\circ} 345$, the brachiopod reacted by growing shell tissue around the hole. e) Trace $\mathrm{n}^{\circ} 293$, the hole occurs in between the two valves. f) $\mathrm{n}^{\circ} 502$, a hole affecting a single valve. g-h) sp. 306, two holes and associated scars, partly overlapping; (g) outer, and (h) inner side of the dorsal valve of the brachiopod host. All scar bars are $1 \mathrm{~cm}$. 
ichnospecies for the trace we deal with in this paper, since it significantly differs from its congenerics. The presence of a subcircular hole couple with a sub-elliptical impression is in fact exclusive to O. taddeii (Fig. 5). O. taddeii differs from $O$. ovalis Bromley and $O$. asperus Nielsen \& Nielsen because the latter are ovoid in shape. Additional Oichnus ichnospecies are sub-circular in external view. $O$. paraboloides from $O$. taddeii for its paraboloid cross section. $O$. gradatus Nielsen \& Nielsen abruptly changes in cross-sectional diameter tapering internally. O. coronatus Nielsen \& Nielsen has the external opening surrounded by a halo having a granular texture. O. excavatus Donovan \& Jagt and emended by Donovan, Blissett \& Pickerill, differs from $O$. taddeii because it does not pierce through the shell, and presents a distinctive central boss. Eventually, the ichnospecie more closely resembling the new trace described here is O. simplex Bromley (1981). Yet, the latter is clearly cylindrical in cross-sectional view, whereas $O$. taddeii cross section suddenly tapers in correspondence to its inner end.

\section{DISCUSSION AND CONCLUSIONS}

The present study contains two different aspects. By one hand, we contribute detailed ichnological information about parasitism on brachiopods in the Quaternary, and new fossil evidence of this parasitic behaviour. Besides, a new Oichnus ichnospecies is proposed on the basis of traces observed on Terebratula shells. It was uneasy to confidently ascribe many of the traces we studied to a precise ichnotaxon. The main reason for this was that until 1999 no capulid individual was ever found in association to the bioerosion.

Taddei Ruggiero (1999) refers to a specimen found on Terebratula terebratula in Gelasian calcarenites outcropping Masseria Poggiofranco. Only the internal mould of the capulid is preserved, and found in nearly anatomical position (Fig. 4a). Borghi (2001) refers to a Gelasian Capulus ungaricus found on a T. terebratula shell in the clay deposits of Stirone river (Emilia, Northern Italy) still in the living position. We present here a third, new specimen of $C$. ungaricus attached to its host brachiopod T. terebratula, coming from the Stirone river outcrop as well (Fig. 4b).

Finding Capulus in association to either pectinids or brachiopods is rare. Such scarcity of remains could possibly depend on the fact that whereas the preservation potential of such taxa is high, gastropods preponderantly have aragonitic shells, that often disappear by solution. It is therefore no coincidence that the findings of capulids still holding to the shells of their host both come from clay sediments.

Even before these specimens were found, the traces we refer to herein were attributed to capulids, in keeping with neontological observations. For instance, Capulus danieli living in New Caledonia drills the shell of the pectinid Comptopallium vexillum and leaves a scar around the hole, 1.5 to $2.5 \mathrm{~mm}$ in diameter, close to the umbo (Orr, 1962). Similarly, Capulus dilatatus produces a distinct attachment area, 4.2 to $33 \mathrm{~mm}$ in diameter, surrounding the hole (1 to

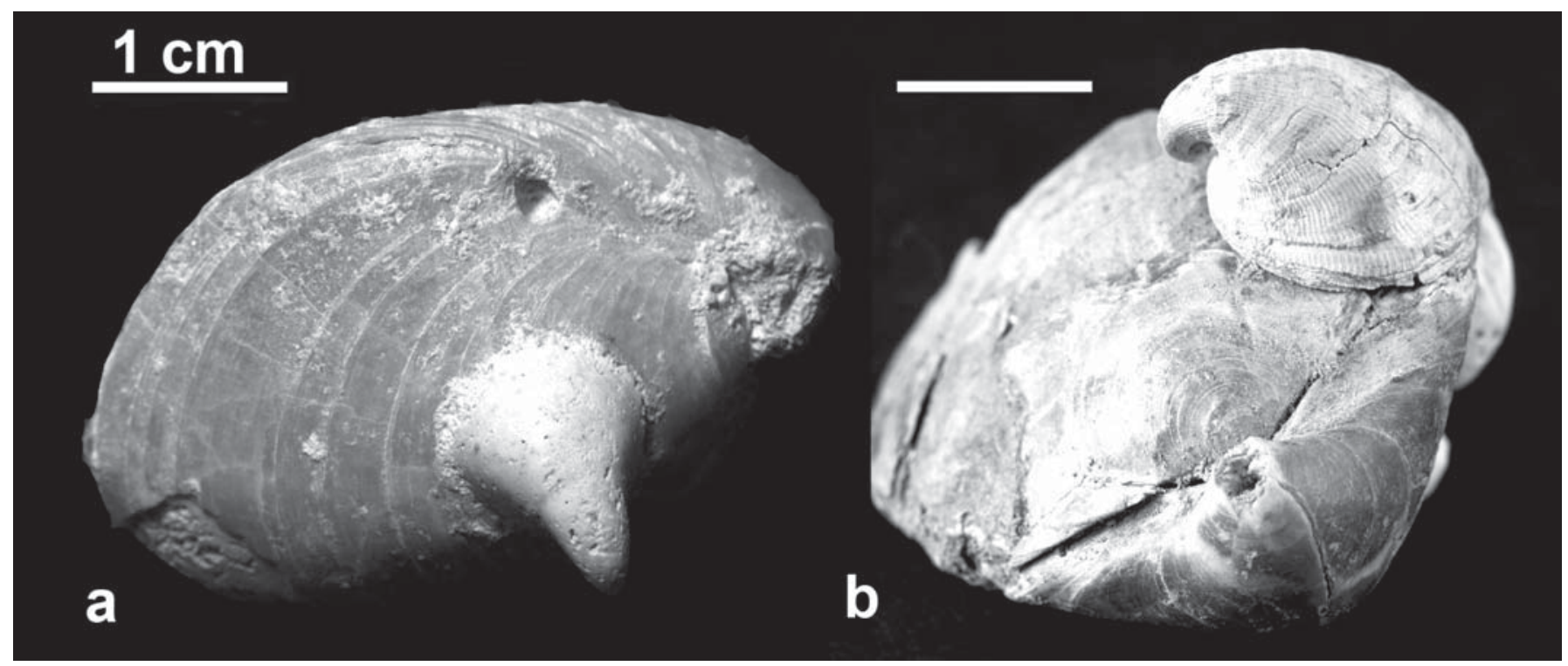

Figure 4. Capulus individuals still attached to their Terebratula terebratula host. a) The specimen $\mathrm{n}^{\circ} 5432$ was found in Gelasian calcarenites outcropping at Canosa (Apulia, Southern Italy); only the internal mould of Capulus was preserved and found nearly in anatomical position. b) Specimen $\mathrm{n}^{\circ} 501$ with C. ungaricus, coming from the Gelasian clay deposits of Stirone river (Emilia, Northern Italy). 


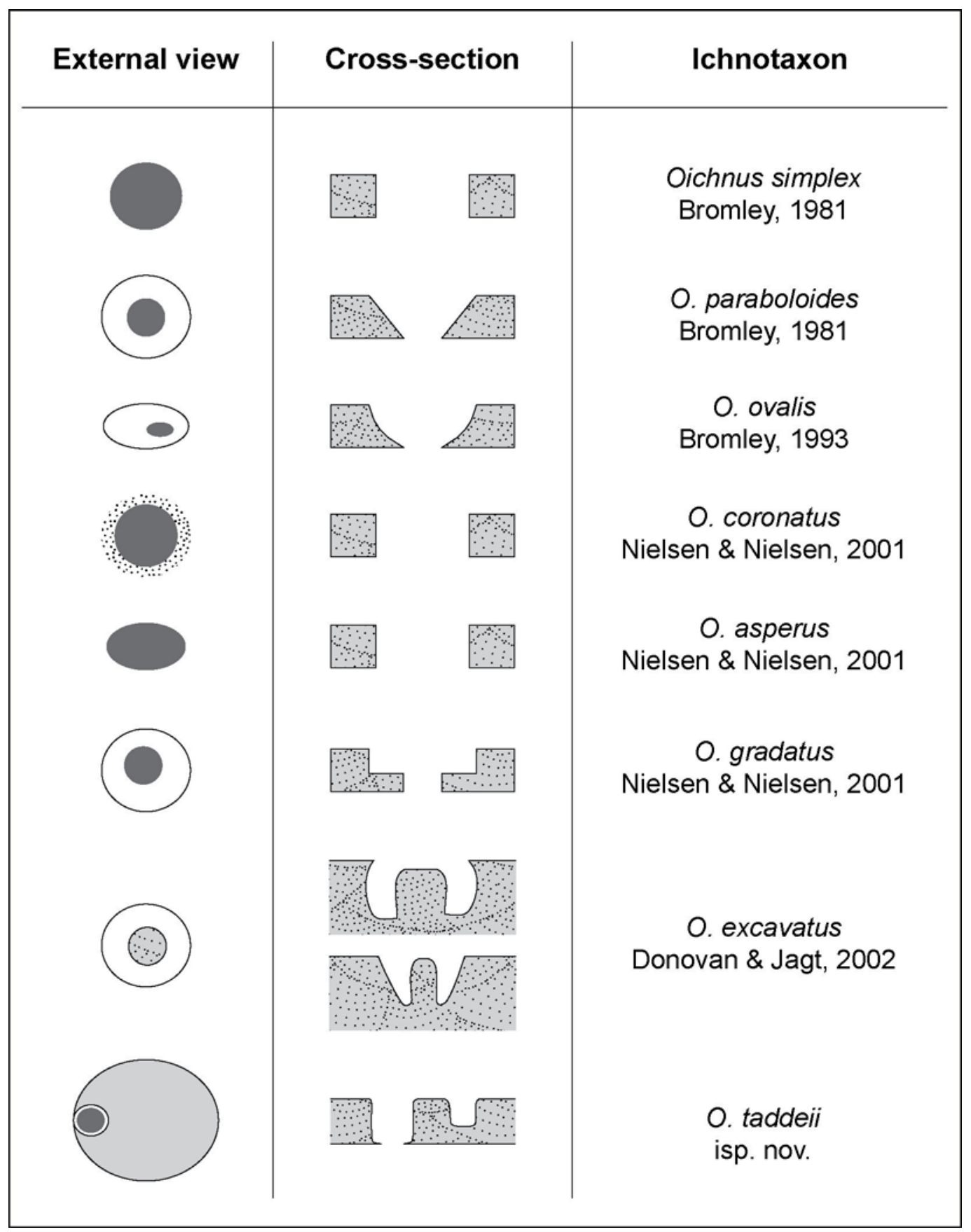

Figure 5. External views and cross-sections of Oichnus ichnospecies, draws are not in the same scale. The portion in white represents the drill hole on the external surface. The black portion represents the section of the trace piercing through the inner side of the shell. Grey, scar on the outer surface of the shell (exclusive to $O$. taddeii). Small dots, granular halo surrounding the trace (exclusive to $O$. coronatus). This figure is modified and expanded after Nielsen \& Nielsen (2001) and Donovan et al. (2003).

$1.67 \mathrm{~mm}$ in diameter), they pierce the umbo of pectinids (Matsukuma, 1978). As for fossil traces, Matsukuma (1978) attributed to C. dilatatus traces found on pectinids from the Early Pleistocene of Japan. The holes, exclusive to the umbo region of the left valve, are 0.74 to $1.52 \mathrm{~mm}$ wide. The attachment area surrounding the holes is 11.6 to $12.7 \mathrm{~mm}$. That is, the trace consistently concerns the activity of Capulus, varying in size in accordance to which particular species left the trace.

From an ecological point of view, heterospecific interactions may be either neutral, positive, or negative (Baumiller \& Gahn, 2002). Parasitism and predation fall 
under the negative interactions category, with one organism exploiting the activities of its host. Capulids behave as (non-obliged) parasites. They find their way to access the inhalant current of bivalves to steal food from their gills (Orr, 1962). Since the shell and the mantle are pierced in the process, the activity of capulids is clearly detrimental to their host, hence the behaviour is correctly envisaged as a form of parasitism. This much rare feeding mode usually concentrates on the apical part of the host shell.

We found on brachiopods similar evidence of piercing capulid activity. Yet, any attribution of those traces remained tentative until we found a capulid shell fossilized on its host's. We thereby conclude that capulids were in fact parasites on brachiopods, and could safely attribute the typical trace they leave to Oichnus taddeii. Still, we suggest that Capulus ungaricus was in fact able to pierce the shell of its host as other living congenerics do. We notice that we never found any faint scar on the brachiopod shells anterior margins, although this happens on bivalves. To us, this suggests that Capulus on brachiopods cannot easily access the host's inhalant current if not by drilling the shell, due to the close commissure between the valves in brachiopods, and to the posterior position of the visceral mass in these organisms.

\section{ACKNOWLEDGEMENTS}

We are grateful to Enrico Borghi who sent us the specimen figured in Fig. 3b. Antonella Taddei and Roberto Graziano kindly helped and assisted us in the preparation of figures and taking pictures of the specimens. Rosa Domènech, Maria Aleksandra Bitner and an anonymous referee kindly reviewed an earlier version of this manuscript providing us with fundamental pieces of advice.

\section{REFERENCES}

Baumiller, T.K. \& Gahn, F.J. 2002. Fossil record of parasitism on marine invertebrates with special emphasis on the platyceratid-crinoid interaction. Paleontological Society Papers, 8, 195-210.

Bongrain, M. 1995. Traces de Bioérosion sur un Pectinidae (Bivalvia) du Miocène d'Aquitaine (SO France) un cas possible de commensalisme entre Pectinidae et Capulidae. Geobios, 28, 347-358.

Borghi, E. 2001. Osservazioni sui brachiopodi neogenici e pleistocenici dell'Emilia. Parva Naturalia. Memorie del Coordinamento dei Musei Scientifici della provincia di Piacenza, 2000-2001, 45-81.

Bromley, R.G. 1981. Concepts in ichnotaxonomy illustrated by small round holes in shells. Acta Geologica Hispanica, $16,55-64$
Donovan, S.K., Blissett, J. \& Pickerill, R.K. 2003. Oichnus excavatus Donovan and Jagt, 2002 from the Moneague Formation, White Limestone. Caribbean Journal of Science, 39, 221-223.

Gibbard, P.L., Head, M.J. \& Walker, M.J.C. 2010. The Subcommission on Quaternary Stratigraphy. Formal ratification of the Quaternary Sistem/Period and the Pleistocene Series/Epoch with a base at $2.58 \mathrm{Ma}$. Journal of Quaternary Sciences, 25, 96-102.

Kowalewski, M. 1993. Morphometric analysis of predatory drillholes. Palaeogeography, Palaeoclimatology, Palaeoecology, 102, 69-88.

Matsukuma, A. 1978. Fossil boreholes made by shell-boring predators or commensals. Part 1: Boreholes of capulid gastropods. Venus, 37, 29-45.

Nielsen, K.S.S., \& Nielsen, J.K. 2001. Bioerosion in Pliocene to late Holocene tests of benthic and planktonic foraminiferans, with a revision of the ichnogenera Oichnus and Tremichnus. Ichnos, 8, 99-116.

Orr, V. 1962. The drilling habit of Capulus danieli (Crosse) (Mollusca Gastropoda). Veliger, 5, 63-67.

Santos, A., Mayoral, E. \& Muñiz, F. 2003. New trace fossils produced by etching molluscs from the Upper Neogene of the southwestern Iberian Peninsula. Acta Geologica Polonica, 53, 181-188.

Santos, A., Mayoral, E. \& Muñiz, F. 2004. Additional note to new trace fossils produced by etching molluscs from the Upper Neogene of the southwestern Iberian Peninsula. Acta Geologica Polonica, 54, 53-54.

Sharman, M. 1956. Note on Capulus ungaricus (L.). Journal of the Marine Biological Association of the U.K., 35, 445-450.

Taddei Ruggiero, E. 1989. Evidenze di predazione e parassitismo su gusci di Brachiopodi. Atti III Simposio Ecologia e Paleoecologia delle Comunità Bentoniche, Catania, 615-631.

Taddei Ruggiero, E. 1991. A study of damage evidence in brachiopod shell. In: Brachiopods through time (eds Mac Kinnon, D.I., Lee, D.E. \& Campbell J.D.). 2nd International Brachiopod Congress. Balkema, Rotterdam, 203-210.

Taddei Ruggiero, E. 1999. Bioerosive processes affecting a population of brachiopods (Upper Pliocene, Apulia). Bulletin of the Geological Society of Denmark, 45, 169-172.

Taddei Ruggiero, E. \& Annunziata, G. 2002. Bioerosion on a Terebratula scillae population from the Lower Pleistocene of Lecce area (Southern Italy). Acta Geologica Hispanica, 37, 43-51.

Taddei Ruggiero, E. \& Bitner, M.A. 2008. Bioerosion on Brachiopod shells: a Cenozoic perspective. In: Brachiopod Research into the Third Millennium (eds Cusack, M. \& Harper, A.T.). Earth and Environmental Science Transactions of the Royal Society of Edinburgh 98, 369-378.

Taddei Ruggiero, E., Raia, P. \& Taddei, A. 2009. Paleopathological cases in Brachiopod shells. Journal of Paleopathology, 21, 63-74. 
